\title{
DESERT ZONE: HISTORY OF WARFARE AND CRIMES COMMITTED BY THE NAZIS IN 1941 ON THE TERRITORY OF THE PRESENT-DAY LIPETSK OBLAST
}

\author{
Nina E. Vashkau \\ Lipetsk State Pedagogical University, Lipetsk, Russian Federation \\ Andrei A. Lakiziuk \\ Lipetsk State Pedagogical University, Lipetsk, Russian Federation
}

\begin{abstract}
Introduction. This research focuses on the previously unexplored Nazi crimes on the territory of the modern Lipetsk Oblast in the fall and winter of 1941. It is conducted as part of the nationwide project "Bez sroka davnosti" (No statute of limitation). Newly declassified information from the archives as well as historical evidence from both sides of the conflict allowed us to present a detailed description of those events. Methods and Materials. We used the principles of historicism and objectivity in order to explain the concept of Hitler's Blitzkrieg against the USSR. We also employed the quantitative method to analyze the structure and equipment of German troops, their readiness for the upcoming battle. Analysis. The leadership of Nazi Germany initially considered the territory of the Soviet Union as their future possessions. Based on this, a policy of treatment of the local population and state property was built, which fits the definition of genocide. The Plans and legal basis for future crimes were developed prior to the outbreak of hostilities. Army corps 45, 134, 95, 262 and 293 Wehrmacht Infantry Divisions, which fought against the $34^{\text {th }}$ and $35^{\text {th }}$ army corps (Red Army), committed various atrocities against the civilian population, as evidenced in detail by archival materials and interrogations of German prisoners of war. Results. The system of the occupation regime was planned in such a way that it was possible to squeeze the maximum out of the occupied lands in favor of Nazi Germany. The behavior of the Wehrmacht soldiers in the occupied territory was destructive in relation to the Soviet population, cultural values and the economy. Technically and morally, the German troops were unable to recover from the defeat received in November-December 1941, while the Red Army was building up its forces and gaining the necessary experience in the fight against the enemy.
\end{abstract}

Key words: Great Patriotic War, "Bez sroka davnosti”, Wehrmacht, occupation, Lipetsk oblast.

Citation. Vashkau N.E., Lakiziuk A.A. Desert Zone: History of Warfare and Crimes Committed by the Nazis in 1941 on the Territory of the Present-Day Lipetsk Oblast. Vestnik Volgogradskogo gosudarstvennogo universiteta. Seriya 4. Istoriya. Regionovedenie. Mezhdunarodnye otnosheniya [Science Journal of Volgograd $\vec{\sim}$ State University. History. Area Studies. International Relations], 2021, vol. 26, no. 4, pp. 125-136. (in Russian). 


\title{
«ЗОНА ПУСТЫНИ»: БОЕВЫЕ ДЕЙСТВИЯ И ПРЕСТУПЛЕНИЯ ПЕХОТНЫХ ДИВИЗИЙ ВЕРМАХТА НА ТЕРРИТОРИИ СОВРЕМЕННОЙ ЛИПЕЦКОЙ ОБЛАСТИ В 1941 ГОДУ
}

\author{
Нина Эмильевна Ваш кау \\ Липецкий государственный педагогический университет им. П.П. Семенова-Тян-Шанского, \\ г. Липецк, Российская Федерация
}

Андрей Александрович Лакизюк

Липецкий государственный педагогический университет им. П.П. Семенова-Тян-Шанского, г. Липецк, Российская Федерация

\begin{abstract}
Аннотация. Введение. Работа посвящена неисследованным аспектам военных преступлений солдат вермахта на оккупированной территории современной Липецкой области осенью - зимой 1941 г. в русле общероссийского проекта «Без срока давности». Новые материалы из архивов, воспоминания, привлеченные с двух сторон, позволяют осветить эту проблему на локальном уровне. Методы и материалы. Принципы историзма и объективности позволили выявить развитие концепции молниеносной войны против СССР. Количественные методы, примененные к характеристике частей вермахта, их качественному и количественному составу, позволили сделать выводы о готовности войск к реалиям военных действий. Результат. Поведение солдат вермахта на оккупированной территории имело разрушительный характер по отношению к советскому населению, культурным ценностям и экономике. Технически и морально вермахт был неспособен оправиться после поражения, полученного в ноябре - декабре 1941 года. В то время как советские войска наращивали силы и приобретали необходимый опыт в борьбе с противником. Вклад авторов: А.А. Лакизюк рассмотрел операции и путь дивизий вермахта, их дислокацию, биографии командующих немецкими частями и соединениями и дал оценку состоянию материального снабжения. Н.Э. Вашкау проанализировала акты ущерба имуществу населения, доказала прямое участие немецких войск в грабежах и расстрелах мирных жителей оккупированных районов, что опровергает легенду о «чистом» вермахте, бытовавшую в послевоенной зарубежной историографии.

Ключевые слова: Великая Отечественная война, «без срока давности», вермахт, оккупация, Липецкая область.

Цитирование. Вашкау Н. Э., Лакизюк А. А. «Зона пустыни»: боевые действия и преступления пехотных дивизий вермахта на территории современной Липецкой области в 1941 году // Вестник Волгоградского государственного университета. Серия 4, История. Регионоведение. Международные отношения. - 2021. T. 26, № 4. - C. 125-136. - DOI: https://doi.org/10.15688/jvolsu4.2021.4.11
\end{abstract}

Введение. Российское историческое общество в 2020 г. инициировало проект «Без срока давности», посвященный теме военных преступлений, совершенных немецко-фашистскими захватчиками и их сообщниками на территории СССР. Боевые действия на фронтах Великой Отечественной войны разворачивались в западных и центральных регионах Советского Союза, в том числе и на территории нынешней Липецкой области. Сюда захватчики вступали дважды: в ходе осенне-зимних боев за Москву в 1941 г. и летом 1942 г. во время проведения операции «Blau». Окончательное освобождение частями Красной ар- мии наступило в конце января 1943 г., после завершения Воронежско-Касторненской наступательной операции.

Среди публикаций по истории Великой Отечественной войны, освещавших события на правом фланге Юго-Западного фронта в ноябре - декабре 1941 г. в рамках сражения за Москву, выделим «Разгром немецко-фашистских войск под Москвой» 1964 г. [17]. В книге «В пламени сражений. Боевой путь 13-й армии» [6] описаны действия армии на территории нашей области. Непосредственно битве под Москвой посвящена книга Клауса Рейнгардта [18]. 
Цель статьи - охарактеризовать сведения о действиях пехотных частей вермахта, которые участвовали в боях ноября - декабря 1941 г. на территории области, проследить судьбу подразделений и командиров, установить причастность руководимых ими частей и соединений к военным преступлениям, совершенным в нашем регионе.

Методы и материалы. В послевоенные годы был издан ряд сборников документов, в которых наглядно демонстрировались преступные замыслы нацистского руководства в отношении СССР [20]. Документы третьего тома «Истории Германии» дополняют информацию о преступных замыслах нацистских руководителей. Сборник «Сожженные деревни России, 1941-1944» содержит протоколы допросов, в том числе и бывших военнослужащих 95-й и 45-й пехотных дивизий (далее пд) вермахта. Именно этим дивизиям противостояли советские войска в 1941-1942 гг. на рассматриваемом направлении.

С ростом внимания к проблеме человека на войне, к повседневной стороне жизни неослабевающий интерес вызывают мемуары советских и немецких генералов и офицеров. Маршал И.Х. Баграмян написал воспоминания о событиях тех лет, основываясь на личном опыте командования частями РККА [4]. Большой интерес вызвала публикация в 1951 г. книги бывшего генерала пехоты вермахта Курта фон Типпельскирха [22]. Ее дополняют воспоминания командующего 2-й танковой армией Гейнца Гудериана [8] и командиров отдельных немецких частей Г. Хейнрици [10].

В настоящее время материалы следственных дел Чрезвычайной государственной комиссии СССР из центральных и региональных архивов активно вводятся в научный оборот и раскрывают страшную «повседневность» войны.

Анализ. Нацистскими лидерами территория СССР рассматривалась как источник ресурсов, необходимых для полноценной жизнедеятельности Германии. Придя к власти, нацисты взялись за возрождение вооруженных сил страны. В 1935 г. был сформирован вермахт и восстановлена всеобщая воинская повинность. Гитлер заявил, что правительством будут предприняты меры, позволяющие отсе- ять из числа военнообязанных лиц тех, кто придерживается марксистского, большевистского или пацифистского воззрений, а также бороться с таковыми, если они будут проникать в войска [13, с. 370-371].

Основной концепцией ведения боевых действий на Востоке стало использование стратегии «молниеносного удара», с целью быстрого сокрушения сил противника в короткие сроки, чтобы не допустить ситуации втягивания Германии в войну на два фронта [20, c. 128-130]. Окончательный план был готов 21 декабря 1940 г. и получил название «Барбаросса». Однако в оценке потенциала соперника аналитические службы вермахта допустили ряд серьезных небрежностей. Такой самокритичный вывод был сделан генералом К. Типпельскирхом после войны.

20 июня 1941 г. А. Розенберг выступил с заявлением, в котором говорилось, что Советский Союз с этого момента рассматривается нацистским руководством как один из объектов немецкой политики, а не как субъект международных отношений. 17 июля 1941 г. было создано так называемое «восточное министерство», которое должно было осуществлять управление оккупированными землями. Практически в каждом населенном пункте, после его захвата, немцы создавали местные органы власти, которые формировались из оккупационных сил и представителей местного населения. Одновременно происходила оценка экономического и людского потенциала занимаемой местности, какие потребности немецкой армии и тыла она могла удовлетворить [20, с. 99].

Деятельность по организации режима курировалась также главным управлением имперской безопасности и верховным командованием вермахта. В документах подведомственного Г. Герингу учреждения «Экономический штаб Ост» подчеркивалось, что главной задачей оккупационной политики является изъятие всех продовольственных ресурсов с целью обеспечения достойного уровня жизни немцев и представителей европейских государств, поддерживающих политику Гитлеpa [20, с. 100]. Штаб разработал план, известный как «Зеленая папка», который предусматривал организованный грабеж захваченных территорий [15, с. 250-253]. Об этом на Нюр- 
нбергском процессе заявил помощник Главного обвинителя от СССР Л.Р. Шейнин 20 февраля 1946 года.

Отметим также акты, которые регулировали обращение с местным населением и военнопленными. Ряд тезисов к Директиве № 21 от 19 мая 1941 г. разъяснял характер ведения войны для немецкого народа как борьбу с большевистской угрозой. Требовалось жестокое подавление любых форм сопротивления, бдительность в отношении военнослужащих РККА, захваченных в плен, выявление командиров, комиссаров и евреев, учет настроений местного населения в отношении немецкой администрации. Рекомендовалось следить и отмечать любые антисоветские настроения [13, с. 405].

Таким образом, можно утверждать, что политика нацистского руководства в отношении захваченных территорий и проживающего на ней населения была последовательно организована и структурирована, планы по ее реализации появились еще до начала боевых действий и корректировались по ходу военной кампании на Востоке.

Бои на территории современной Липецкой области начались с оккупации 23 ноября 1941 г. Становлянского района. Частям вермахта была поставлена задача прикрывать правый фланг и тыл 2-й танковой армии Гудериана, которая должна была овладеть г. Тула [8, с. 280-289]. Состав этих подразделений постоянно менялся, корпуса и дивизии переподчинялись крупным формированиям в зависимости от обстановки. 2-я полевая армия Вейхса должна была взять под контроль железнодорожный узел г. Елец, сеть шоссейных дорог и переправы через р. Дон.

Немецким войскам противостояла 13-я армия Юго-Западного фронта под командованием генерал-майора А.М. Городнянского, которая сумела выйти из окружения под городом Брянском. В задачу армии входило оборонять Елецко-Ливенское направление [6, с. 42-45].

В журналах боевых действий войск Юго-Западного фронта и 13-й армии отмечалось, что наступлению на данном участке противник придавал большое значение и сосредоточил два армейских корпуса, в составе которых насчитывалось до 6 пд - 45, 95, 134, 262, 293 и 54. О том, что в районе Ельца противник развернул такое количество войск, советскому командованию стало известно 7 декабря 1941 г. [9, л. 17]. До этого момента номера некоторых частей противника были известны руководству 13-й армии, однако точное количество войск на передовой определялось примерно - до батальона или полка.

Кратко охарактеризуем каждое из подразделений, противостоявших советским войскам в боях на липецкой земле.

XXXV армейским корпусом (далее $\mathrm{AK)} \mathrm{командовал} \mathrm{генерал} \mathrm{артиллерии} \mathrm{Рудольф}$ Кемпфе, участник Первой мировой войны, Польской и Французской кампаний. Имел правительственные награды. До 1942 г. оставался в должности командира корпуса, но осенью того же года был отправлен в резерв. Подозревался в организации покушения на А. Гитлера 20 июля 1944 г., был арестован гестапо, где содержался до капитуляции Германии. После войны находился в плену в СССР. Освобожден в 1949 г. [25].

XXXIV AK командовал генерал пехоты Герман Мец. Участник Первой мировой войны, преподавал военную историю в военной академии в Берлине. Вместе со своим корпусом попал в окружение в декабре 1941 года. Оставил войска и улетел из «кольца» на присланном за ним самолете. Этот факт был зафиксирован штабом группы генерала К.С. Москаленко, которая преследовала отступающего к г. Ливны противника [7, л. 116]. После поражения корпус генерала Меца был расформирован, а сам командующий пробыл в вермахте до начала 1943 г. [27].

45 пд вермахта участвовала в овладении Брестской крепостью, прошла в направлении Барановичи - Пинск - Гомель [5, с. 42]. Дивизия имела колоссальный опыт ведения боевых действий. После боев за г. Елец она попала в окружение и была практически полностью уничтожена. После декабрьских боев на липецкой земле в составе 45 пд осталось всего 800 человек. Начальник Генерального штаба Ф. Гальдер признал соединение небоеспособным и снял с фронта, однако дивизия была доукомплектована и возвращена в строй [26, p. 83]. Командовал дивизией в этот период генерал-лейтенант Фриц Шлипер. После боевых действий и окружения, в феврале 1942 г. оставил командование и был откоман- 
дирован в Словакию. В мае 1945 г. был взят в плен союзниками и освобожден в 1947 году. Умер в 1977 г. [28].

134 пд вермахта была сформирована осенью 1940 года. В боевых действиях на Восточном фронте участвовала в составе группы армии «Центр» на направлении Белосток Бобруйск. Затем сражалась под Киевом и Брянском. Подразделением с мая 1940 г. командовал генерал-лейтенант Конрад фон Кохенгаузен [26, p. 155-157]. 13 декабря 1941 г., отказавшись покинуть войска на присланном за ним самолете, командующий дивизией погиб при невыясненных обстоятельствах [4, c. 282]. Дивизия находилась на Орловском направлении до 1943 года.

95 пд вермахта участвовала во Французской кампании лета 1940 года. На Восточном фронте действовала в составе группы армий «Юг». Во время ноябрьского наступления должна была наносить удар по станции Касторное, а затем обеспечить прорыв войск 45 и 134 пд из окружения, но ввиду плохо организованной разведки вышла под наступающие части группы генерала Ф.Я. Костенко и была практически полностью уничтожена. В окружение не попала благодаря изменению направления удара оперативной группы генерала Костенко [9, л. 21, 23]. В дальнейшем дивизия воевала на Волге и под Ржевом. Окончательно разгромлена под Кёнигсбергом [26, p. 133]. Командовал подразделением Ганс-Генрих Зикт фон Арним. Попал в плен в ходе Сталинградской битвы.

262 пд вермахта была сформирована в 1939 г. в Австрии. Начала путь на Саарском фронте. На Восточном фронте участвовала в боях под Бродами, Житомиром, Киевом и Брянском [26, p. 246-247]. В рассматриваемый период располагалась на северном участке, на стыке 13-й и 3-й армий. Во время отступления сумела избежать окружения [5, с. 43]. Оставалась на Орловском направлении, участвовала в сражении на Курской дуге. Командовал соединением генерал-лейтенант Эдгар Тайссен. Пленен американскими союзниками, в 1947 г. освобожден. После убийства его семьи бывшими русскими остарбайтерами стал патером католической церкви. Умер в 1968 г. [29].

293 пд вермахта была сформирована весной 1940 г. и участвовала в боях во Фран- ции. Летом 1941 г. в составе группы армий «Центр» подразделение прошло на направление Гомель - Чернигов - Киев - Орел. Находилась на стыке советских 3-й и 13-й армий. Основной задачей подразделения было захватить и удерживать железнодорожный узел в г. Ефремов Тульской области. После начала контрнаступления советских войск дивизия с большими потерями покинула занимаемые рубежи [5, с. 43-44]. Командущий - генераллейтенант Юстин фон Оберниц после поражения под Москвой и по состоянию здоровья оставил пост. Уволен в запас в 1943 году. Умер в 1955 г. [30].

О действиях 54 пд в нашем регионе информации найти не удалось.

Наступательные темпы немецкой армии были уже несопоставимы с летом 1941 года. За две недели, начиная с 20 ноября (захват г. Ливны) по 6 декабря (позиции под г. Елец), гитлеровцы вклинились на 70 км вглубь советских позиций и растянулись по фронту на 130 км. Для удержания фронта было необходимо своевременно подтягивать резервы, обеспечивать бесперебойную работу тыловых служб, а с этим вермахт испытывал серьезные трудности.

Рассмотрим, в каком положении оказались солдаты вермахта, сражавшиеся на территории рассматриваемых районов. В начале наступления войск на Москву обнаружилась проблема обеспечения горюче-смазочными материалами танковых частей. Гудериан, наступавший в начале октября на Орловском направлении, писал позднее, что поставку горючего в войска осуществляли, порой, при помощи авиации. Часто колонны бензовозов штурмовала советская авиация [8, с. 268]. Раскисшие грунтовые дороги стали непроходимыми не только для автомашин, но и для танков. Моторесурс двигателей быстро изнашивался, тягачам и вездеходам приходилось тянуть грузы сверх положенного объема. Поломка и отказ транспортных средств серьезным образом сказывались на доставке в войска самого необходимого - боеприпасов, вооружения, обмундирования, пищи и писем из дома. Особенно страдали солдаты вермахта от нехватки зимней одежды и плохого питания. Командующий XXXXIII АК Г. Хейнрици отмечал, что из-за отсутствия зимнего обмун- 
дирования его подчиненные чаще выбывают с передовой по причине обморожений и сопутствующих болезней, чем от результатов боевыХ действий $[10$, с. 22, 150]. Части 293 пд потеряли до 30 \% личного состава таким образом [24].

Возникли перебои с поставками продовольствия. Часто бойцы вермахта не имели возможности приготовить горячую пищу. Когда позволяли условия, в частях организовывали самостоятельные производства - пекли хлеб, доили коров и т. д. С самолетов периодически сбрасывали продукты, но они могли оказаться совсем не теми, на которые рассчитывали. Так, генерал Хейнрици упоминает об эпизоде, когда в контейнерах доставили мармелад вместо тушенки и жира $[10$, с. 127,135$]$.

Руководство полагало, что части, воюющие на Восточном фронте, будут самостоятельно решать задачи по обеспечению себя продовольствием. Сельское хозяйство Германии было не способно на постоянной основе кормить свою огромную армию, куда, к тому же, шел отток рабочих рук из деревень. Для решения проблемы предполагались изъятие продовольствия и ресурсов с оккупированных территорий и интенсивное использование труда военнопленных. Однако расчеты немецкого руководства провалились. Летний урожай, который оккупанты планировали собрать, достался далеко не в полном объеме. Во многом это был результат работы местных жителей и партизанских соединений. Иногда и сами грабители вынуждены были уничтожать часть захваченной продукции, поскольку были не в состоянии воспользоваться ею или переправить в тыл. При этом командование вермахта не считалось с интересами местного населения [18, с. 190-193].

Вторая проблема - это психологическое состояние войск. Кратко характеризуя части, воевавшие на липецкой земле, мы видим, что подразделения победным маршем проходили через Беларусь и Украину, окружали советские части под Киевом и Брянском в страшных «котлах». Воодушевление от стремительных побед, уверенность в скором завершении операции демонстрируют письма и фотографии солдат и офицеров с фронта домой [23, c. 80]. Однако с наступлением серьезных трудностей в войсках вермахта происходят резкие психологические изменения. В мемуapax отмечается падение боевого духа, потеря смысла этой войны многими бойцами. От развала подразделения сдерживали только ветераны, закаленные в боях, и общая дисциплинированность. Генерал Типпельскирх отмечал, что вермахт вообще был не готов ни материально, ни морально наступать зимой 1941 г. [22, с. 354-356]. И.Х. Баграмян, служивший зимой 1941 г. в штабе Юго-Западного фронта, вспоминал, в каком виде он застал пленных немецких солдат, захваченных в ходе Елецко-Ливенской операции: «Первым был капитан - квартирьер 95 пд, закутанный в пуховый платок с чехлами из овчины на сапогах. А солдаты были испуганными, уставшими, с большим количеством вшей. У одного из них из-под каски в качестве подшлемника видны были женские рейтузы» [4, с. 271, 278].

Непогода, плохое снабжение, тяжелые фронтовые будни, безусловно, сказывались на настроении немцев. Война изначально начала складываться не так успешно, как планировалось, и причиной тому было отчаянное сопротивление советских солдат, даже в условиях окружения. К. Типпельскирх отмечал, что русские, нанося удары на, казалось бы, безнадежных с военной точки зрения участках фронта, медленно, но верно сдерживали наступательные порывы вермахта. Генерал Г. Хейнрици поражался тому, с каким упорством русские части бьются в окружении. Еще больше его впечатлили партизаны, особенно подростки, которые без страха сражались с врагом и были готовы отдать свои жизни ради защиты Родины [10, с. 117-121]. Сказывалось и возросшее умение советских солдат сражаться со слаженной немецкой армией. Командиры научились гасить высокий темп наступления противника за счет создания глубокоэшелонированных линий обороны, эффективной и продуманной системы противотанковой и противовоздушной защиты, а также применения тактики постоянных контрударов и контратак. Все это не позволяло противнику поддерживать прежние темпы наступления и закрепляться на занятых позициях [17, с. 148-150].

Бойцы РККА сражались в равных условиях с солдатами вермахта. Точно также испытывали и голод, и нужду. Все те же проблемы по части снабжения. К тому же, они в 
основном отступали весь 1941 г. с большими потерями. Отмечался недостаток боеприпасов и тяжелого вооружения, нехватка транспортных средств. Успех зимнего контрнаступления советских войск под Москвой кроется в грамотной оценке оперативной обстановки, сложившейся на фронте, а также в высокой моральной устойчивости наших бойцов, которые сражались за свою землю, против иноземного захватчика [17, с. 150-154].

В местах постоя гитлеровцы постоянно оставляли следы своих преступлений. В разгар войны 2 ноября 1942 г. была создана Чрезвычайная государственная комиссия по установлению и расследованию злодеяний немецко-фашистских захватчиков и их сообщников и причиненного ими ущерба гражданам, колхозам, общественным организациям, государственным предприятиям и учреждениям СССР. До учреждения данного органа сбором информации занимались представители местной власти.

Архивные документы областей и республик СССР, находившихся под оккупацией, сохранили доказательства грабительской политики вермахта. Они полностью опровергают оценки его как «чистого» вермахта.

Так, Измалковскому району Липецкой области был нанесен ущерб на сумму 39599350 руб., Воловскому - на 594 млн руб., Долгоруковскому - 59726140 руб., г. Елец 116093000 руб., Становлянскому - более 500 млн [11], Тербунскому - более 10 млн руб. [14, с. 109-116]. Сотни людей погибли во время боевых действий, от показательных казней мирных жителей. В ходе работы с актами установлено, что большинство карательных акций было направлено против мужского населения и военнопленных РККА, которых подозревали в участии в партизанском движении. Повсеместно были зарегистрированы факты уничтожения женщин, детей и стариков. За время оккупации в Измалковском районе было убито 43 человека (из них 2 ребенка и 3 женщины), в Елецком - 46 человек [16], в Становлянском - 68 человек (из них 5 детей) [12], в Долгоруковском - 70 человек [1].

Местное население и военнопленных угоняли на принудительные работы в Германию. Из Становлянского района было угнано 122 человека [11], еще около 500 (военноплен- ных) удалось освободить наступающим частям Красной армии во время боев за село Россошное 11 декабря 1941 г. [9, л. 31], из Воловского и Елецкого районов было угнано свыше 600 человек [14, с. 106-107, 113-115]. Полной информацией по оставшимся районам мы на сегодняшний день не располагаем.

Грабеж населения происходил на протяжении всего времени нахождения в населенных пунктах войск вермахта. Солдаты забирали практически все вещи, которые могли найти. В качестве примера приведем перечень изъятого имущества у жителя с. Гермушино Измалковского района Шеховцова Пармена Артемовича: 4 пуда мяса, 3 пуда овса, 5 пудов гороха, 3 полотенца, 2 пары мужских тапок, 1 кальсоны, 2 курей, 3 женских рубахи, 42 кг хлеба, 3 копны сена и т. д. [2].

Эти деяния носили грабительский и разрушительный характер, в делах встречаются факты, указывающие на сознательную порчу имущества. При подсчете общих убытков, причиненных оккупантами Измалковскому району, только зерна было сожжено на сумму более 3,5 млн рублей [19]. Огромное количество разрушенного и сожженного имущества - домов, конюшен, складов и т. д. Часть имущества и припасов, которыми по какойлибо причине немецкие солдаты не смогли воспользоваться или вывезти, попросту уничтожалась на месте. Таким образом, местное население сознательно обрекалось на голод и лишалось крова в зимний период.

Германское командование не препятствовало стихийному грабежу, если это не ставило под угрозу военные задачи. Поощрение личной материальной заинтересованности в войне не раз становилось мотивом преступлений против мирного населения [15, с. 257].

Некоторые фронтовые генералы и офицеры вермахта понимали, что удержать захваченные позиции и наступать дальше не получится, войска выдохлись и нуждались в отдыхе и пополнении. На участке фронта 2-й полевой армии разрабатывался план организации оборонительного рубежа и отвода сил за него. Предполагалось отойти из района Ельца на запад примерно на 20 км и обустроить позиции. Отвод войск должен был сопровождаться созданием так называемой «зоны пустыни» - всю местность от г. Елец (его планиро- 
валось полностью уничтожить) до укрепленного района необходимо было полностью выжечь [18, с. 213-214]. В Долгоруковском районе был сожжен и уничтожен 461 колхозный дом, в Становлянском - более 3000 домов, в отдельных колхозах и деревнях более $90 \%$ построек [14, с. 93-95], в Измалковском районе местные жители свидетельствовали о массовых поджогах населенных пунктов и гибели людей (был заживо сожжен в своем доме житель с. Круглое И.В. Золотов) [3].

Приказы по созданию такой зоны действительно были. Так, генерал Ганс Зикет фон Арним издавал распоряжения подобного рода, которые неукоснительно выполнялись. Командующий свою вину в преступлениях против мирных граждан в ходе допроса признавать отказался [21, с. 439-441].

Солдаты лично принимали участие в сожжении ряда деревень, изъятии имущества и депортации населения на работу в Германию. Из протокола допроса солдата Карла Рутцендорфера: «...Приказы о создании зоны пустыни на пути своего отступления всеми подразделениями нашей дивизии выполнялись безоговорочно. Так, по пути отступления из г. Елец по направлению Змиевки в декабре 1941 года я видел, как все населенные пункты на расстоянии 50-60 км горели...». В таком же ключе свидетельствовал о своих преступных деяниях бывший военнослужащий 95 пд Отто Освальд [21, с. 424-426, 438-439].

Планам удержания захваченных территорий не суждено было сбыться. Начавшееся наступление 13-й армии А.М. Городнянского и оперативной группы генерала Ф.Я. Костенко позволило практически полностью разгромить силы XXXIV и XXXV АК вермахта. В ходе Елецко-Ливенской наступательной операции противник лишился большого количества военного имущества, было уничтожено порядка 12 тыс. солдат и офицеров, 300 взято в плен [9, л. 34]. Это было самым крупным поражением вермахта с начала битвы за Москву. До этого момента немецкие части в основном сами организовывали и ликвидировали так называемые «котлы». Теперь деморализованный противник испытал все трудности окружения. В ходе освобождения населенных пунктов солдаты Красной армии становились первыми свидетелями преступлений, учинен- ных оккупантами. В журнале боевых действий 13-й армии от 9 декабря содержится сообщение о том, что противник сжигает населенные пункты [7, л. 103].

Результаты. В процессе подготовки к ведению войны против СССР германское командование предусматривало жесткую структуру функционирования, обращения и распределения экономического потенциала противника. Система оккупационного режима была спланирована таким образом, чтобы можно было выжать максимум из захваченных земель в пользу нацистской Германии. Поведение солдат вермахта на оккупированной территории регламентировалось предвоенными инструкциями и имело разрушительный характер по отношению к советскому населению, культурным ценностям и экономике.

Территория области находилась в зоне активных боевых действий и оккупации порядка трех недель. Однако за это время противник причинил весьма ощутимый ущерб. Работы по его подсчету начались практически сразу после освобождения, неоднократно обновлялись и дополнялись. Несмотря на бытующее мнение о «чистом вермахте» десятилетия после войны в германском обществе, невозможно игнорировать факт участия в расправах солдат вермахта. Это сломанные жизни и судьбы не только погибших, но и их семей и родственников. Читая архивные документы, восстанавливая цепь событий, мы понимаем, какой порядок готовили будущие хозяева на советской земле и характер борьбы, которую вел советский народ в этой войне.

Подразделения вермахта, бывшие в ноябре - декабре 1941 г. в боях на липецкой земле, так и не смогли окончательно оправиться после поражения, полученного в ходе попытки организовать удар на Москву с Юго-Западного направления. До конца войны части 2-й полевой армии были либо расформированы, либо влились в состав других соединений. Германские солдаты и офицеры, которые продолжали вести эту войну, все больше в ней разочаровывались.

Ни один из генералов вермахта, воевавших на липецкой земле в 1941 г., не сумел продвинуться по карьерной лестнице наверх. Поражение на данном участке фронта оказалось принять очень тяжело. Практически никто из 
них не получил какого-либо серьезного наказания за свои преступления. Оказавшись в зоне оккупации союзников, они отбыли, по сути, формальные сроки тюремного заключения и смогли вернуться к обычной жизни. За убийство одного человека современное уголовное право предусматривает более суровое наказание, нежели то, которое понесли генералы и солдаты вермахта, виновные в сознательном геноциде народов.

\section{СПИСОК ЛИТЕРАТУРЫ}

1. Акт Долгоруковской районной комиссии о злодеяниях, совершенных немецко-фашистскими войсками в период оккупации района // Государственный архив Липецкой области (далее ГАЛО). - Ф. Р-2491. - Оп. 1. - Д. 17. - Л. 70.

2. Акт от 11 февраля 1942 г. об изъятии личного имущества у Шеховцова П.А. немецкими захватчиками // ГАЛО. - Ф. Р-2491. - Оп. 1. - Д. 11. Л. 9.

3. Акт от 13 ноября 1944 г. о сожжении в собственном доме гражданина Золотова И. В. немецко-фашистскими войсками // ГАЛО. - Ф. Р-2491. Оп. 1. - Д. 24. - Л. 65.

4. Баграмян, И. Х. Так шли мы к победе / И. Х. Баграмян. - М. : Воениздат, 1988. - 638 с.

5. Баранов, В. Дивизии вермахта на Восточном фронте. ГРУ Красной армии: гриф секретности снят / В. Баранов. - Екатеринбург : Издательские решения, 2017. $-66 \mathrm{c}$.

6. В пламени сражений. Боевой путь 13-й армии / М. А. Козлов. - М. : Воениздат, 1973. - 344 с.

7. Выписка из журнала боевых действий штаба 13 А за период с 21.08.41 по 02.10.41 г. // Центральный архив министерства обороны (далее ЦАМО). - Ф. 361. - Оп. 0006079. - Д. 0026. - Электрон. текстовые дан. - Режим доступа: https:/pamyatnaroda.ru/documents/view/?id $=451006664 \&$ backurl=division $\% 5 \mathrm{C} 13 \% 20 \mathrm{~A}:$ :begin_date $\% 5 \mathrm{C} 30.10 .1941$ ::end_date\%5C06.12.1941::use_main_string\%5 Ctrue::group\%5Cjbd::types\%5Cjbd\&date_from $=$ 30.10.1941\&date_to=06.12.1941 (дата обращения: 10.08.2020). - Загл. с экрана.

8. Гудериан, Г. Воспоминания солдата / Г. Гудериан. - М. : Вече, 2012. -560 c.

9. Журнал боевых действий войск фронта за декабрь 1941 г. // ЦАМО. - Ф. 229. - Оп. 161. Д. 179. - Электрон. текстовые дан. - Режим доступа: https://pamyat-naroda.rudocuments/view/ ?id $=114814083 \&$ backurl $=$ division $\% 5 \mathrm{C} 150 \% 20 \%$ D1\%82\%D0\%B1\%D1\%80::begin_date\%5C06.12.1941:: end_date $\% 5$ C06.12.1941::use_main_string\%5Ctrue:: group $\% 5$ Call::types $\% 5$ Copersvodki:rasporyajeniya:o tcheti:peregovori:jbd:direktivi:prikazi:posnatovleniya: dokladi:raporti:doneseniya:svedeniya:plani:plani operaciy:karti:shemi:spravki:drugie::page $\%$ 5 C3\&date from $=06.12 .1941 \&$ date to $=06.12 .1941$ \&division $=150 \% 20 \% \mathrm{D} 1 \% 82 \% \mathrm{D} 0 \% \mathrm{~B} 1 \% \mathrm{D} 1 \% 80$ (дата обращения: 10.08.2020). - Загл. с экрана.

10. Заметки о войне на уничтожение. Восточный фронт 1941-1942 гг. в записях генерала Хейнрици / под ред. Й. Хюртера ; пер. с нем., предисл. к рус. изд. О. И. Бэйды, И. Р. Петрова. - СПб. : Изд-во Европ. ун-та в Санкт-Петербурге, 2018. - 328 с.

11. Из доклада секретаря Становлянского райкома ВКП(б) В. Андреева на районном собрании партийного советского и комсомольского актива Становлянского района Орловской области // Государственный архив новейшей истории Липецкой области. - Ф. 55. - Оп. 1. - Д. 66. - Л. 58-59.

12. Из докладной записки, составленной Становлянской районной комиссией, по ущербу от злодеяний немецко-фашистских войск в период оккупации района // ГАЛО. - Ф. Р-2491. - Оп. 1. - Д. 8. - Л. 12.

13. История Германии. В 3 т. Т. 3. Документы и материалы : учеб. пособие / под общ. ред. Б. Бонвеча, Ю. В. Галактионова. - М. : Изд-во КДУ, 2008. - 592 с.

14. Липецкий край в годы Великой Отечественной войны / под общ. ред. А. Т. Березнева. - Липецк : Ориус, 2005. - 403 с.

15. Нюрнбергский процесс : сб. материалов в 8 т. / отв. ред. А. Я. Сухарев. - М. : Юрид. лит., 1990. T. $4 .-672 \mathrm{c}$.

16. Обобщенные сведения об установленных злодеяниях, учиненных над гражданами СССР немецко-фашистскими оккупантами по Елецкому и Измалковскому районам Орловской области // ГАЛО. Ф. Р-2491. - Оп. 1. - Д. 21. - Л. 3 ; Д. 24. - Л. 2-3.

17. Разгром немецко-фашистских войск под Москвой / под ред. Маршала Советского Союза В. Д. Соколовского. - М. : Воениздат, 1964. - 444 с.

18. Рейнгардт, К. Поворот под Москвой / К. Рейнгардт ; пер. с нем. Г. М. Иваницкого. - М. : Вече, 2010. $-410 \mathrm{c}$.

19. Сведения об убытках, причиненных немецко-фашистскими захватчиками Измалковскому району в 1944 г. // ГАЛО. -Ф. Р-2491. - Оп. 1. - Д. 26. - Л. 4.

20. «Совершенно секретно! Только для командования!». Стратегия фашистской Германии в войне против СССР : документы и материалы / сост. В. И. Дашичев. - М. : Наука, 1967. - 742 с.

21. Сожженные деревни России, 1941-1944 : документы и материалы / сост. Н. В. Кириллова, В. Д. Селеменева. - М. : Фонд «Историческая память», 2017. $-607 \mathrm{c}$.

22. Фон Типпельскирх, К. История Второй мировой войны. Блицкриг / К. фон Типпельскирх. М. : Вече, 2016. - 464 c. 
23. «...Хоть раз напишу тебе правду». Письма солдат вермахта из сталинградского окружения / сост. Н. Э. Вашкау. - М. : Рос. полит. энцикл. (РОССПЭН), 2013. - 135 c.

24. 293 Infanterie-division. - Electronic text data. Mode of access: http://www.lexikon-der-wehrmacht. de/Gliederungen/Infanteriedivisionen/293ID.htm (date of access: 01.09.2020). - Title from screen.

25. Kaempfe, Rudolf. - Electronic text data. Mode of access: http:/www.lexikon-der-wehrmacht.de/ Personenregister/K/KaempfeRudolf.htm (date of access: 01.09.2020). - Title from screen.

26. Mitcham, S. W. German order of battle / S. W. Mitcham. - Mechanicsburg : Stackpole Books, 2007. -293 p. - (Stackpole military history series).

27. Metz, Hermann. - Electronic text data. - Mode of access: http://www.lexikon-der-wehrmacht.de/ Personenregister/M/MetzHermann.htm (date of access: 01.09.2020). - Title from screen.

28. Schlieper, Fritz Albert Otto. - Electronic text data. - Mode of access: http://www.lexikon-derwehrmacht.de/Personenregister/S/SchlieperFritz.htm (date of access: 01.09.2020). - Title from screen.

29. Theißen, Edgar. - Electronic text data. - Mode of access: http:/www.lexikon-der-wehrmacht.de/ Personenregister/T/TheissenEdgar.htm (date of access: 01.09.2020). - Title from screen.

30. Von Obernitz, Justin. - Electronic text data. Mode of access: http://www.lexikon-der-wehrmacht.de/ Personenregister/O/ObernitzJustinv.htm (date of access: 01.09.2020). - Title from screen.

\section{REFERENCES}

1. Akt Dolgorukovskoy rayonnoy komissii o zlodeyaniyakh, sovershennykh nemetsko-fashistskimi voyskami v period okkupatsii rayona [The Act of the Dolgorukovsky District Commission on Atrocities Committed by the German Fascist Troops During the Occupation of the Area]. Gosudarstvennyy arkhiv Lipetskoy oblasti (GALO) [State Archive of the Lipetsk Region (GALO)], f. R-2491, op. 1, d. 17, 1. 70.

2. Akt ot 11 fevralya 1942 g. ob izyatii lichnogo imushchestva u Shekhovtsova P.A. nemetskimi zakhvatchikami [Act of February 11, 1942 on the Withdrawal of Personal Property from Shekhovtsov P.I. by the German Invaders]. GALO, f. R-2491, op. 1, d. 11, 1.9.

3. Akt ot 13 noyabrya 1944 g. o sozhzhenii v sobstvennom dome grazhdanina Zolotova I.V. nemetskofashistskimi voyskami [The Act of November 13, 1944 on the Burning of the Citizen Zolotov I.V. in His Own House by the German Fascist Troops]. GALO, f. R-2491, op. 1, d. $24,1.65$.

4. Bagramyan I.Kh. Tak shli my k pobede [So We Went to Victory]. Moscow, Voyenizdat Publ., 1988. 638 p.
5. Baranov V. Divizii vermakhta na Vostochnom fronte. GRU Krasnoy armii: Grif sekretnosti snyat [Wehrmacht Divisions on the Eastern Front. GRU of the Red Army: The Secrecy Label is Removed]. Ekaterinburg, Izdatelskiye resheniya Publ., 2017. 66 p.

6. Vplameni srazheniy. Boyevoy put 13-y armii [In the Flames of Battle. The Combat Path of $13^{\text {th }}$ Army]. Moscow, Voyenizdat Publ., 1973. 344 p.

7. Vypiska iz zhurnala boyevykh deystviy shtaba 13 A za periods 21.08 .41 po $02.10 .41 \mathrm{~g}$. [Extract from the Journal of Combat Operations of Headquarters 13 A for the Period from 21.08.41 to 02.10.41]. Tsentralnyy arkhiv ministerstva oborony (TsAMO) [Central Archive of the Ministry of Defense (TsAMO)], f. 361, op. 0006079, d. 0026, 1. 146. URL: https://pamyatnaroda.ru/documents/view/?id $=451006664 \&$ backurl=division $\% 5 \mathrm{C} 13 \% 20 \mathrm{~A}:$ :begin_date $\% 5 \mathrm{C}$ 30.10.1941::end_date\%5C06.12.1941::use_main_ string\%5Ctrue::group\%5Cjbd::types\%5Cjbd\&date from $=30.10 .1941 \&$ date to $=06.12 .1941$ (accessed 10 August 2020).

8. Guderian G. Vospominaniya soldata [Memories of a Soldier]. Moscow, Veche Publ., 2012. $560 \mathrm{p}$.

9. Zhurnal boyevykh deystviy voysk fronta za dekabr 1941 g. [Journal of Combat Operations of the Front Troops for December 1941]. TsAMO, f. 229, op. 161, d. 179. URL: https://pamyat-naroda. rudocuments/view/?id=114814083\&backurl= division $\% 5 \mathrm{C} 150 \% 20 \% \mathrm{D} 1 \% 82 \% \mathrm{D} 0 \% \mathrm{~B} 1 \% \mathrm{D} 1 \% 80:$ : begin_date $\% 5 C 06.12 .1941::$ end_date $\% 5 C 06.12 .1941::$ use_main_string\%5Ctrue::group $\% 5$ Call::types $\%$ 5Copersvodki:rasporyajeniya:otcheti:peregovori: jbd:direktivi:prikazi:posnatovleniya:dokladi:raporti: doneseniya:svedeniya:plani:plani_operaciy:karti: shemi:spravki:drugie::page $\% 5 C 3 \&$ date_from $=06.12 .1941$ \&date to $=06.12 .1941 \&$ division $=150 \% 20 \% \mathrm{D} 1 \%$ $82 \% \mathrm{D} 0 \% \mathrm{~B} 1 \% \mathrm{D} 1 \% 80$ (accessed 10 August 2020).

10. Zametki o voyne na unichtozheniye. Vostochnyy front 1941-1942 gg. v zapisyakh generala Kheynritsi [Notes on the War of Annihilation. The Eastern Front 1941-1942 in General Heinrici's Notes]. Saint Petersburg, Izdatelstvo Evropeyskogo universiteta v Sankt-Peterburge, 2018. 328 p.

11. Iz doklada sekretarya Stanovlyanskogo raykoma VKP(b) V. Andreyeva na rayonnom sobranii partiynogo sovetskogo i komsomolskogo aktiva Stanovlyanskogo rayona Orlovskoy oblasti [From the Report of the Secretary of the Stanovlyansky District Committee of the All-Union Communist Party (Bolsheviks) V. Andreev at the District Meeting of the Party Soviet and Komsomol Activists of the Stanovlyansky District of the Orel Region]. Gosudarstvennyy arkhiv noveyshey istorii Lipetskoy oblasti [State Archive of Contemporary History of the Lipetsk Region], f. 55, op. 1, d. 66, 1. 58-59. 
12. Iz dokladnoy zapiski, sostavlennoy Stanovlyanskoy rayonnoy komissiyey, po ushcherbu ot zlodeyaniy nemetsko-fashistskikh voysk v period okkupatsii rayona [From the Memo Compiled by the Stanovlyansky District Commission on the Damage Caused by the Atrocities of the German Fascist Troops During the Occupation of the Area]. GALO, f. R-2491, op. 1, d. 8, 1. 12.

13. Bonvech B., Galaktionov Yu.V., eds. Istoriya Germanii. V 3 t. T. 3. Dokumenty i materialy: ucheb. posobiye [German History. In 3 Vols. Vol. 3. Documents and Materials. Study Guide]. Moscow, KDU, 2008. 592 p.

14. Bereznev A.T., ed. Lipetskiy kray $v$ gody Velikoy Otechestvennoy voyny [Lipetsk Region During the Great Patriotic War]. Lipetsk, Orius Publ., 2005. $403 \mathrm{p}$.

15. Sukharev A.Ya., ed. Nyurnbergskiy protsess: sb. materialov $v 8$ t. T. 4 [The Nuremberg Trials. Collection of Materials in 8 Vols. Vol. 4]. Moscow, Yuridicheskaya literatura Publ., 1990.672 p.

16. Obobshchennyye svedeniya ob ustanovlennykh zlodeyaniyakh, uchinennykh nad grazhdanami SSSR nemetsko-fashistskimi okkupantami po Eletskomu i Izmalkovskomu rayonam Orlovskoy oblasti [General Information About the Identified Atrocities Committed Against the Citizens of the USSR by the German Fascist Occupiers in the Yelets and Izmalkovsky Districts of the Orel Region]. $G A L O$, f. R-2491, op. 1, d. 21, 1. 3; d. 24, 1.2-3.

17. Sokolovskiy V.D., ed. Razgrom nemetskofashistskikh voysk pod Moskvoy [Defeat of the German Fascist Troops Near Moscow]. Moscow, Voyenizdat Publ., 1964. 444 p.

18. Reyngardt K. Povorot pod Moskvoy [Turn Near Moscow]. Moscow, Veche Publ., 2010. 410 p.

19. Svedeniya ob ubytkakh, prichinennykh nemetsko-fashistskimi zakhvatchkami Izmalkovskomu rayonu v 1944 g. [Information About the Losses Caused by the German Fascist Invaders to the Izmalkovsky District in 1944]. GALO, f. R-2491, op. 1, d. $26,1.4$.
20. Dashichev V.I., ed. «Sovershenno sekretno! Tolko dlya komandovaniya!». Strategiya fashistskoy Germanii v voyne protiv SSSR: dokumenty i materialy ["Top Secret! Only for the Command!" The Strategy of Fascist Germany in the War Against the USSR. Documents and Materials]. Moscow, Nauka Publ., 1967. 742 p.

21. Kirillova N.V., Selemeneva V.D., eds. Sozhzhennyye derevni Rossii, 1941-1944: dokumenty $i$ materialy [Burned Villages of Russia, 1941-1944. Documents and Materials]. Moscow, Fond «Istoricheskaya pamyat», 2017. 607 p.

22. Kurt fon Tippelskirkh. Istoriya Vtoroy mirovoy voyny. Blitskrig [History of the Second World War. Blitzkrieg]. Moscow, Veche Publ., 2016. 464 p.

23. Vashkau N.E., ed. "... Khot raz napishu tebe pravdu». Pisma soldat vermakhta iz stalingradskogo okruzheniya [I'll Write You the Truth for Once. Letters of Wehrmacht Soldiers from the Stalingrad Encirclement]. Moscow, Rossiyskaya politicheskaya entsiklopediya (ROSSPEN) Publ., 2013. 135 p.

24. 293 Infanterie-Division. URL: http:// www.lexikon-der-wehrmacht.de/Gliederungen/ Infanteriedivisionen/293ID.htm (accessed 1 September 2020).

25. Kaempfe, Rudolf. URL: http://www.lexikonder-wehrmacht.de/Personenregister/K/KaempfeRudolf. htm (accessed 1 September 2020).

26. Mitcham Samuel W. German Order of Battle. Mechanicsburg, Stackpole Books, 2007. 293 p. (Stackpole Military History Series).

27. Metz, Hermann. URL: http://www.lexikon-derwehrmacht.de/Personenregister/M/MetzHermann.htm (accessed 1 September 2020).

28. Schlieper, Fritz Albert Otto. URL: http:// www.lexikon-der-wehrmacht.de/Personenregister/S/ SchlieperFritz.htm (accessed 1 September 2020).

29. Theißen, Edgar. URL: http://www.lexikon-derwehrmacht.de/Personenregister/T/TheissenEdgar.htm (accessed 1 September 2020).

30. Von Obernitz, Justin. URL: http://www.lexikonder-wehrmacht.de/Personenregister/O/ObernitzJustinv. htm (accessed 1 September 2020). 


\section{РУСЬ, РОССИЙСКАЯ ИМПЕРИЯ И СССР}

\section{Information About the Authors}

Nina E. Vashkau, Doctor of Sciences (History), Professor, Chair of Russian and World History, Lipetsk State Pedagogical University, Lenina St, 42, 398020 Lipetsk, Russian Federation, vaschkau@mail.ru, https://orcid.org/0000-0001-9181-4381

Andrei A. Lakiziuk, Master Student, Lipetsk State Pedagogical University, Lenina St, 42, 398020 Lipetsk, Russian Federation, andr512@mail.ru, https://orcid.org/0000-0003-2350-5186

\section{Информация об авторах}

Нина Эмильевна Вашкау, доктор исторических наук, профессор кафедры русской и всемирной истории, Липецкий государственный педагогический университет им. П.П. Семенова-Тян-Шанского, ул. Ленина, 42, 398020 г. Липецк, Российская Федерация, vaschkau@mail.ru, https://orcid.org/0000-0001-9181-4381

Андрей Александрович Лакизюк, магистрант, Липецкий государственный педагогический университет им. П.П. Семенова-Тян-Шанского, ул. Ленина, 42, 398020 г. Липецк, Российская Федерация, andr512@mail.ru, https://orcid.org/0000-0003-2350-5186 